\title{
Further studies on hydration of alkynes by the $\mathrm{PtCl}_{4}-\mathrm{CO}$ catalyst
}

\author{
Osnat Israelsohna, K. Peter C. Vollhardt ${ }^{b}$, and Jochanan Blum ${ }^{a}{ }^{*}$ \\ a Department of Organic Chemistry, The Hebrew University, Jerusalem 91904, Israel \\ ${ }^{b}$ Center for New Directions in Organic Synthesis, Department of Chemistry, University of \\ California and the Chemical Sciences Division, Lawrence Berkeley National Laboratory, Berkeley, \\ California 94720-1460, USA
}

Dedicated to Professor Myron Rosenblum on the occasion of his $75^{\text {th }}$ birthday in recognition of his outstanding contribution to chemistry

\begin{abstract}
Under $\mathrm{CO}$ atmosphere, between 80 and $120^{\circ} \mathrm{C}$, a glyme solution of $\mathrm{PtCl}_{4}$ forms a carbonyl compound that promotes hydration of internal as well as terminal alkynes to give aldehyde-free ketones. The catalytic process depends strongly on the electronic and steric nature of the substrates. Part of the carbonyl functions of the catalyst can be replaced by phosphine ligands. Chiral DIOP reacts with the $\mathrm{PtCl}_{4}-\mathrm{CO}$ compound to give a catalyst that promotes partial kinetic resolution of a racemic alkyne. Replacement of part of the $\mathrm{CO}$ by polystyrene-bound diphenylphosphine enables to attach the catalyst to the polymeric support. Upon entrapment of the platinum compound in a silica sol-gel matrix, it reacts as a partially recyclable catalyst. A reformulated mechanism for the $\mathrm{PdCl}_{4}-\mathrm{CO}$ catalyzed hydration is suggested on the basis of the present study.
\end{abstract}


Keywords: Platinum; Carbon monoxide; Alkynes; Hydration

* Corresponding author: Fax: +972-2-6513832; e-mail address: jblum@chem.ch.huji.ac.il.

\section{Introduction}

In a previous study [1], we have shown that, under $\mathrm{CO}$ atmosphere in boiling aqueous $\mathrm{THF}, \mathrm{PtCl}_{4}$ catalyzes the hydration of several alkynes to give aldehyde-free saturated ketones according to eq (1). Upon extension of these studies, we realized that

$$
\mathrm{RC} \equiv \mathrm{CR}^{1}+\mathrm{H}_{2} \mathrm{O} \rightarrow \mathrm{RCOCH}_{2} \mathrm{R}^{1}+\mathrm{RCH}_{2} \mathrm{COR}^{1}
$$

in some cases the ketones are accompanied by considerable amounts of high molecular weight condensation products, as well as some alkenes that result from the water assisted transfer-hydrogenation of the alkynes. In addition, we noticed that minute changes in the reaction conditions could be associated with significant variations in the results and consequently lead to low reproducibility. Particular remarkable fluctuations in the yields were observed in the hydration of $\mathrm{C}_{6} \mathrm{H}_{5} \mathrm{C} \equiv \mathrm{CH}, \mathrm{C}_{6} \mathrm{H}_{5} \mathrm{C} \equiv \mathrm{C}_{6} \mathrm{H}_{5}$, and $\mathrm{C}_{6} \mathrm{H}_{5} \mathrm{C} \equiv \mathrm{CCO}\left(\mathrm{CH}_{2}\right)_{2} \mathrm{CH}_{3}$ mentioned in our previous paper [1]. Therefore, we found it imperative to investigate the main factors that influence the desired and the undesired processes, to optimize the reaction conditions, and to try to broaden the scope of the catalytic hydration. In this paper we report the dependence of the catalytic hydration of alkynes on the nature of the organic solvent, on the amount of water, on the electronic and steric structure of the substrate, and on the $\mathrm{CO}$, as well as on other additives to the platinum salt. We also report the possibility of using a chiral catalyst for induction of asymmetry during the addition of water to a racemic alkyne. 


\section{Experimental}

\subsection{General}

${ }^{1} \mathrm{H}$ and ${ }^{13} \mathrm{C}$ NMR spectra were recorded on Bruker AMX-300 and AMX-400 instruments. MS measurements were performed on a Hewlett-Packard model 4989A mass spectrometer equipped with both an HP gas chromatograph model 5890 Series II and a particle beam interface system with an HPLC model 1050. IR spectra were taken on a Bruker Vector 22 FTIR spectrometer. Gas chromatographic separations and analyses were carried out with the aid of a Hewlett-Packard GC model 417, and a Varian-Aerograph instrument model 920. HPLC separation of none chiral products were performed on a Jasco TRI-ROTAR IV machine equipped with a DG-3510 degasser and a UVIDEC 100-VI UV spectrophotometer. The hydration experiments were carried out either in a Parr bench top micro reactor series 4591 with a temperature controller 4841, equipped with a mechanical stirrer and a sampler, or in a $45 \mathrm{ml}$ Parr pressure vessel model 4712 with a gage block No. 4316 furnished with a magnetic stirrer. Optical rotation measurements were taken on a Perkin-Elmer polarograph model 141 equipped with a sodium lamp. Separation of partially resolved 1,3,5-triphenylpent-4-yn-1-one was made for us by Regis Technologies, Inc. (Morton Grove, Illinois) on a Pirkle Type $(S, S)$ ULMO column.

Most commercially available starting materials were purchased from Farchan Division of Story Chemical Corporation and from Aldrich Chemical Co. 1,4-Diphenyl1,3-butadiyne [2], 1,5,9-decatriyne [3], 1-phenyl-1-hexyn-3-one [4], 2,7-dimethyloct-1-en3-yne [5], 3-ethyoxy-1,3-phenylbut-1-yne [6], 2-ethynylfuran [7], 2-ethynylthiophene [7], 
1- and 2-phenylethynylnaphthalene [8], and 1,3,5-triphenylpent-4-yn-1-one [9] were prepared as described in the literature. The various 4-substituted phenylacetylenes $\mathrm{XC}_{6} \mathrm{H}_{4} \mathrm{C} \equiv \mathrm{CH}$, as well as the substituted diphenylacetylenes $\mathrm{XC}_{6} \mathrm{H}_{4} \mathrm{C} \equiv \mathrm{CC}_{6} \mathrm{H}_{5}$, were prepared either by treatment of the corresponding aryl iodide with trimethylsilylacetylene followed by hydrolysis or by the reaction of the iodides with phenylacetylene in the presence of $\mathrm{PdCl}_{2}\left(\mathrm{PPh}_{3}\right)_{2}$ and $\mathrm{Cu}_{2} \mathrm{I}_{2}[10]$.

\subsection{General procedure for the hydration of alkynes}

The following procedure was employed for the hydration of most alkynes. A solution of $50.5 \mathrm{mg}(0.15 \mathrm{mmol})$ of $\mathrm{PtCl}_{4}$ in $2 \mathrm{ml}$ of $92 \%$ aqueous glyme and $7.5 \mathrm{mmol}$ of the alkyne was placed in a miniautoclave. The reaction vessel was flushed $(3 \mathrm{x})$ with carbon monoxide and then pressurized with the same gas to 200 psi. The autoclave was then introduced into an oil bath, thermostated at $108^{\circ} \mathrm{C}$ and the reaction mixture stirred at 350-400 rpm for the desired length of time. The mixture was concentrated under reduced pressure. The concentrate was extracted with a suitable solvent (usually $\mathrm{CH}_{2} \mathrm{Cl}_{2}$ ) and chromatographed on either silica gel or alumina. The resulting products were analyzed by the usual spectroscopic methods and, when possible, compared with authentic samples. Some representative results obtained under these conditions are summarized in Table 1. For the kinetic measurement, an autoclave with sampler was used and the CO pressure was adjusted after each sampling.

\subsection{Partial kinetic resolution of 1,3,5-triphenylpent-4-yn-1-one by hydration}


To a solution of $10 \mathrm{mg}\left(3 \times 10^{-2} \mathrm{mmol}\right)$ of $\mathrm{PtCl}_{4}$ and $15 \mathrm{mg}\left(3 \times 10^{-2} \mathrm{mmol}\right)$ of $(4 R, 5 R)-$ (-)-O-isopropylidene-2,3-dihydroxy-1,4-bis(diphenylphosphino)butane ( $R, R$-DIOP) in 2.5 $\mathrm{ml}$ of dry glyme was added a solution of $25.1 \mathrm{mg}(0.81 \mathrm{mmol})$ of 1,3,5-triphenylpent-4yn-1-one [9] in $1 \mathrm{ml}$ of glyme and $70 \mu \mathrm{l}$ of water. The reaction mixture was then treated as described above with $\mathrm{CO}$ at $108^{\circ} \mathrm{C}$ for $16.5 \mathrm{~h}$. After the usual work-up, the resulting material was separated on silica gel using a 1:10 mixture of ether-hexane as eluent to give $201 \mathrm{mg}$ of starting material and $53 \mathrm{mg}$ (20\%) of 1,3,5-triphenylpentane-1,5-dione, $\mathrm{mp} 84^{\circ} \mathrm{C}$ [11]. The recovered alkyne was optically active; $0.8^{\circ}, 25^{\circ} \mathrm{C}, 589 \mathrm{~nm}, \mathrm{CHCl}_{3}, \mathrm{c}=$ 1; which indicates $3 \%$ ee [12]. The same ee was obtained by HPLC analysis on a $250 \times 4.6$ mm Pirkle Type $(S, S)$-ULMO column with a mobile phase of $99.5 \%$ hexane and $0.5 \%$ of 2-propoanol; flow rate $1 \mathrm{ml} / \mathrm{min}$.

\section{Results and Discussion}

Like some other platinum compounds that promote hydration of acetylenes $[4,13]$ our $\mathrm{PtCl}_{4}-\mathrm{CO}$ catalyst was found to be highly sensitive to the reaction conditions and its activity influenced by a variety of factors.

\subsection{Solvent effect}

Hydration of phenylacetylene in the presence of $8 \mathrm{~mol}$ of water and $200 \mathrm{psi} \mathrm{CO}$ in (i) dioxane, (ii) $\mathrm{THF}$, (iii) ethyl acetate, (iv) glyme, and (v) diglyme at $108^{\circ} \mathrm{C}$ formed after $12 \min 6,16,25,26$, and $26 \%$ of acetophenone, respectively. The reaction under phase transfer conditions using tricaprylmethylammonium chloride as phase transfer catalyst and either 1,1,2,2-tetrachloroethane or benzene as the organic medium, afforded 4-12\% 
of the expected ketone. On the basis of these results, we conducted our standard hydration experiments either in aqueous glyme or diglyme.

\subsection{Effect of the amount of water}

The hydration in diglyme proved to be first order in $\mathrm{H}_{2} \mathrm{O}$ at low water concentration $(<6 \mathrm{M})$, but above $7 \mathrm{M}$ the rate of formation of $\mathrm{PhCOCH}_{3}$ decreased sharply (Table 2). As the optimal amount of water was $8-12 \%$, we used $88-92 \%$ of aqueous diglyme (or glyme) in our standard experiments.

Replacement of $\mathrm{H}_{2} \mathrm{O}$ by $\mathrm{D}_{2} \mathrm{O}$ was associated with a primary kinetic isotope effect, $\operatorname{rate}(\mathrm{H}) / \operatorname{rate}(\mathrm{D})=2.5$, and the resulting ketones were found by $400 \mathrm{MHz}{ }^{1} \mathrm{H}\left\{{ }^{2} \mathrm{D}\right\}$ NMR to be $8 \% \mathrm{C}_{6} \mathrm{H}_{5} \mathrm{COCH}_{3}, 26 \% \mathrm{C}_{6} \mathrm{H}_{5} \mathrm{COCH}_{2} \mathrm{D}, 42 \% \mathrm{C}_{6} \mathrm{H}_{5} \mathrm{COCHD}_{2}$, and $24 \% \mathrm{C}_{6} \mathrm{H}_{5} \mathrm{COCD}_{3}$. Control experiments show that part of the deuterium labeling results from platinum catalyzed H-D exchange of acetophenone with $\mathrm{D}_{2} \mathrm{O}$.

\subsection{Dependence on the amount of $\mathrm{PtCl}_{4}$ and the mode of its application}

Experiments in which $7.5 \mathrm{mmol}$ of phenylacetylene in $2 \mathrm{ml}$ of diglyme and varying amounts of $\mathrm{PtCl}_{4}$ (from 0.032 to $0.188 \mathrm{mmol}$ ) were reacted for 12 min periods with 0.16 $\mathrm{ml} \mathrm{H}_{2} \mathrm{O}$ at $108^{\circ} \mathrm{C}$ under 200 psi of $\mathrm{CO}$ revealed that the hydration is first order in the platinum compounds for $\left[\mathrm{PtCl}_{4}\right]<70 \mathrm{mM}$. Above $75 \mathrm{mM}$ the process becomes practically independent of the catalyst. An identical rate dependence was observed when these experiments were conducted in glyme instead of diglyme.

In our preliminary experiments [1], we carried out the hydrations in two steps: in the first step, we treated the platinum salt at $100^{\circ} \mathrm{C}$ with $\mathrm{CO}$ under a pressure of $200 \mathrm{psi}$, 
and in the second step the green complex was heated with the substrate at $80^{\circ} \mathrm{C}$ under 20 psi CO. We have now found that the process gives the most reproducible results in a one step process in which all components are heated at $105-110{ }^{\circ} \mathrm{C}$ under 200 psi CO. Thus, the standard hydration experiments could be optimized by using $0.075-0.125 \mathrm{M}$ solutions of $\mathrm{PtCl}_{4}$ in $8 \%$ aq. glyme at $108^{\circ} \mathrm{C}$.

\subsection{Scope of reaction}

Several representative alkynes that had not been studied in our preliminary work, as well as phenylacetylene, diphenylacetylene, and 1-phenyl-1-octyn-2-one that gave irreproducible results, were investigated under the improved conditions. The results are summarized in Table 1.

Table 1 indicates that the hydration takes place with terminal and internal aliphatic, aromatic, as well as sulfur heterocyclic alkynes to give aldehyde-free ketones. As the ketonic products formed from terminal acetylenes have reactive acetyl moieties that may undergo slow undesired catalytic condensations, we limited the reaction time of these substrates to $12-20 \mathrm{~min}$, during which the condensation processes are still negligible. Diarylacetylenes give ketones that do not undergo condensation. Owing to their bulkiness, they require, however, longer reaction times of several hours. During this extended period, two side reaction occurred occasionally. Diphenylacetylene (entry 5 in Table 1) and 1,4-diphenylbutadiyne (entry 7), but not 2-naphthylphenylacetylene (entry 6), underwent water-assisted transfer hydrogenation to give substantial amounts of the corresponding cis- and trans-olefins. The second side reaction, which in most cases did not exceed $0.5 \%$, was hydrochlorination of the alkynes. The formation of $\mathrm{HCl}$ is the 
result of hydrolysis of the platinum salt. Only in the hydration of 1-phenyl-1-hexyn-3one were $6 \%$ of chlorinated olefins obtained (entry 9). The formation of $2 \%$ of $\mathrm{C}_{6} \mathrm{H}_{5} \mathrm{COCH}=\mathrm{CCl}\left(\mathrm{CH}_{2}\right) \mathrm{CH}_{3}$ is rationalized by rearrangement of the starting alkynone to $\mathrm{C}_{6} \mathrm{H}_{5} \mathrm{COC} \equiv \mathrm{C}\left(\mathrm{CH}_{2}\right)_{2} \mathrm{CH}_{3}$ prior to the addition of $\mathrm{HCl}[4]$.

Under our reaction conditions, only two molecules of water added to 1,5,9decatriyne [3] in the first $20 \mathrm{~min}$. Interestingly, the major product was $\mathrm{CH}_{3} \mathrm{CO}\left(\mathrm{CH}_{2}\right)_{3} \mathrm{CO}\left(\mathrm{CH}_{2}\right)_{2} \mathrm{C} \equiv \mathrm{CH}(37 \%)$. The diketones $\mathrm{CH}_{3} \mathrm{CO}\left(\mathrm{CH}_{2}\right)_{2} \mathrm{C} \equiv \mathrm{C}\left(\mathrm{CH}_{2}\right)_{2} \mathrm{COCH}_{3}$ and $\mathrm{CH}_{3} \mathrm{CO}\left(\mathrm{CH}_{2}\right)_{2} \mathrm{CO}\left(\mathrm{CH}_{2}\right)_{3} \mathrm{C} \equiv \mathrm{CH}$ were obtained in only 10 and $9 \%$, respectively (entry 8). The enyne, $\mathrm{H}_{2} \mathrm{C}=\mathrm{C}\left(\mathrm{CH}_{3}\right) \mathrm{C} \equiv \mathrm{C}\left(\mathrm{CH}_{2}\right)_{2} \mathrm{CH}\left(\mathrm{CH}_{3}\right)_{2}$ [5], yielded mainly $\mathrm{H}_{2} \mathrm{C}=\mathrm{C}\left(\mathrm{CH}_{3}\right) \mathrm{CH}_{2} \mathrm{CO}\left(\mathrm{CH}_{2}\right) \mathrm{CH}\left(\mathrm{CH}_{3}\right)_{2}$ in which the carbonyl function is located at the least hindered position. The only byproduct in this reaction was $2 \%$ of the partially hydrogenated alkyne.

\subsection{Dependence on the substrate}

At low substrate concentration (0.937-3.75 M), the hydration of phenylacetylene proved to be practically independent of the substrate during the first five minutes, during which no side products are detectable. At substrate concentrations $>3.75 \mathrm{M}$, the reaction slows. The dependence of the rate of hydration of phenylacetylene on the concentration of the substrate between 0.937 and $4.688 \mathrm{M}$ is summarized in Table 3 .

We attribute this catalyst "poisoning" with excessive substrate to blocking of active sites which interferes with the coordination of the water. The reaction rate proved to depend significantly on the electronic and steric nature of the substrate. Experiments conducted under comparable conditions with some substituted phenylacetylenes 
revealed that the initial hydration rates of $4-\mathrm{CH}_{3} \mathrm{C}_{6} \mathrm{H}_{4} \mathrm{C} \equiv \mathrm{CH}, 4-\mathrm{CH}_{3} \mathrm{OCH}_{4} \mathrm{C} \equiv \mathrm{CH}$, 4$\mathrm{FC}_{6} \mathrm{H}_{4} \mathrm{C} \equiv \mathrm{CH}$, and $4-\mathrm{ClC}_{6} \mathrm{H}_{4} \mathrm{C} \equiv \mathrm{CH}$ were $6.92 \times 10^{-4}, 6.51 \times 10^{-4}, 2.60 \times 10^{-4}$, and $9.20 \times 10^{-5}$ mol $\mathrm{l}^{-1} \mathrm{~s}^{-1}$. From the logarithm of these data and the $\sigma_{\mathrm{p}}$ values suggested by Sjöström and Wold [14], a Hammett plot could be drawn and the $\rho$ value of $2.20 \pm 0.03$ deduced. This value suggests partial positive charge formation in the rate determining step [15]. A quite similar electronic effect was observed during the hydration of internal alkynes. The substrates of choice were substituted diphenylacetylenes which react much more slowly than the phenylacetylenes, but do not undergo condensation reactions. The results of some comparative experiments are summarized in Table 4 . The only byproducts were cis- and trans-stilbene derivatives formed by water-assisted transfer hydrogenation. The latter products could be separated readily from the ketones by chromatographic methods. Despite the general trend that alkynes with electron donating substituents in the para position react relatively fast and those with electron attracting groups react slowly, the results listed in Table 4 cannot be expressed very well as a Hammett plot. In this series, one should notice that while $4-\mathrm{CH}_{3} \mathrm{C}_{6} \mathrm{H}_{4} \mathrm{C} \equiv \mathrm{C}_{6} \mathrm{H}_{5}$ forms 4- $\mathrm{CH}_{3} \mathrm{C}_{6} \mathrm{H}_{4} \mathrm{COCH}_{2} \mathrm{C}_{6} \mathrm{H}_{5}$ and $4-\mathrm{CH}_{3} \mathrm{C}_{6} \mathrm{H}_{4} \mathrm{CH}_{2} \mathrm{COC}_{6} \mathrm{H}_{5}$ as the major and minor products, respectively, the diarylacetylenes with electron attracting substituents yield, in preference, ketones in which the carbonyl group is conjugated with the substituted phenyl moiety.

Steric factors have an even stronger influence than the electronic effect on the hydration of alkynes in aqueous glyme (see entry 6 in Table 4). In aqueous THF and under phase transfer conditions, the steric effect is less pronounced than in glyme [1]. 
The carbonyl moiety in the single product of sterically hindered $2-\mathrm{CH}_{3} \mathrm{C}_{6} \mathrm{H}_{4} \mathrm{C} \equiv \mathrm{C}_{6} \mathrm{H}_{5}$ is conjugated to the non-substituted phenyl ring.

Further significant steric effects have been observed in the hydration of the naphthylacetylenes. While 2-(phenylethynyl)napthalene forms slowly the two expected ketones in equal amounts (Table 1, entry 6), the more hindered 1-(phenylethynyl)naphthalene does not react at all under the same conditions. Likewise, 9-(phenylethynyl)phenanthrene [16] and 1,2-bis(phenylethynyl)benzene [17] proved inactive.

\subsection{Effect of the temperature and the stirring rate}

The hydration of the alkynes proved to take place over a considerable range of temperatures. Phenylacetylene hydration was studied between 80 and $120^{\circ} \mathrm{C}$ and found to yield during the first 10-15 min practically pure acetophenone. Thereafter, however, the product underwent significant condensation (vide infra). Therefore, our determination of the rate dependence on the temperature was based only on the initial rates. Measurements were carried out between 87 and $117^{\circ} \mathrm{C}(360-390 \mathrm{~K})$ for several substrate concentrations between 0.8 and $1.2 \mathrm{M}$. In a set of experiments in which a 1.01

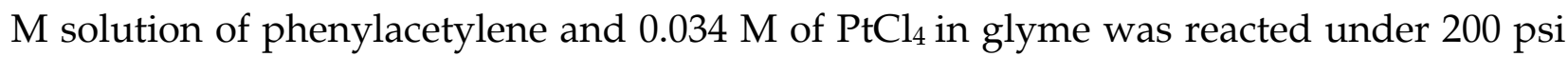
$\mathrm{CO}$, the initial rates of acetophenone formation at $87,97,113$, and $117^{\circ} \mathrm{C}$ were 0.0125 , $0.0325,0.505$, and $0.716 \mathrm{~mol} \mathrm{l}^{-1} \mathrm{~s}^{-1}$. From the Arrhenius plot of $\ln$ (initial rate) against $1 / \mathrm{T}$ $x 10^{-3}$, the apparent activation energy $E_{a}=7.16 \mathrm{kcal} \mathrm{mol}^{-1}$ was deduced. This surprisingly low value suggests that the hydration takes place under heterogeneous conditions and in diffusion, rather than being chemically controlled [18]. Support for this suggestion is 
found in the observation that the reaction depends strongly on the stirring rate. In order to eliminate this factor from our studies, we have tuned our stirrers to $390 \mathrm{rpm}$.

We believe that the heterogeneous nature of the catalytic system is associated with the initial formation of insoluble clusters of platinum complexes. A possibility that metallic platinum particles are formed during the process can be ruled out by our experiments with metallic nanoparticles (prepared by reduction of a THF solution of $\mathrm{K}_{2} \mathrm{PtCl}_{4}$ by $\mathrm{NaBH}_{4}$ in the presence of $\left.\left[\left(\mathrm{C}_{8} \mathrm{H}_{17}\right)_{3} \mathrm{NCH}_{3}\right]\right)$ [19], which proved completely inactive, and by the fact that XPS studies of the used catalyst did not reveal the presence of any $\operatorname{Pt}(0)$.

\subsection{Role of the $\mathrm{CO}$ and of other ligands}

While $\alpha$-alkynones can be hydrated by $\mathrm{PtCl}_{4}$ in the absence of CO [4], most alkynes react efficiently only in its presence. As we have shown [1] that both the kinetics of the addition of water to alkynes by our $\mathrm{PtCl}_{4}-\mathrm{CO}$ system and the IR bands of the reacting complex resemble those obtained with $\mathrm{H}_{2}\left[\mathrm{Pt}_{3}(\mathrm{CO})_{3}(\mu-\mathrm{CO})_{3}\right]_{n}(\mathrm{n}=5,6)$ [20], we suggest that in the presence of traces of $\mathrm{HCl}$ both platinum containing materials are precursors to one and the same catalyst $\mathrm{HPtCl}(\mathrm{CO})_{2}$ [1]. Since we found that there are some alkynes, apart from $\alpha$-alkynones, that can be transformd to ketones in aqueous glyme or diglyme without $\mathrm{CO}$, we conclude that there must be more than one route for the hydration of alkynes. For example, when in the hydration of phenylacetylene at $108^{\circ} \mathrm{C}$ under 200 psi CO (that yielded $85 \%$ acetophenone after $25 \mathrm{~min}$ ), the CO was replaced by $\mathrm{N}_{2}$ (200 psi) or $\mathrm{CO}_{2}$ (80 psi), the yield of the ketone dropped to 33 and $23 \%$, respectively. When the process was conducted under ambient conditions, $20 \%$ of acetophenone was 
isolated. In the various experiments without $\mathrm{CO}$, significant amounts of condensation products of high molecular weight were obtained, even at the short reaction period of 20 min. This proves that the CO-containing system is a better hydration than condensation catalyst (vide infra).

Despite these observations, it was feasible to replace part of the CO by various ligands without increasing the amount of undesired polycondensation products, although large amounts of the additive decreased the rate of hydration. Under conditions in which the $\mathrm{PtCl}_{4}-\mathrm{CO}$ catalyst yielded $60 \%$ of acetophenone, the addition of 20,33 , and $100 \mathrm{~mol} \%$ of triphenylphosphine to the reaction mixture furnished 66,43 , and $23 \%$ of acetophenone. Thus, a small amount of the phosphine is not only not deleterious but even increases the rate. Under the same conditions, the addition of an equimolar amount of of triphenyl phosphite yielded 31\% of acetophenone, and $40 \mathrm{~mol} \%$ of the bidentate (S)-(-)-2,2'-bis(diphenylphosphino)-1,1'-binaphthalene gave $18 \%$ of the ketone.

Because the hydration of some alkynes was reported to take place by metal-free formic, acetic, and some mineral acids [21], we investigated the possibility that the hydration process is associated with the high acidity of the $\mathrm{PtCl}_{4}-\mathrm{CO}$ solution. In experiments with $\mathrm{C}_{6} \mathrm{H}_{5} \mathrm{C} \equiv \mathrm{CH}$ in which the platinum catalyst was replaced by $\mathrm{HCl}$, $\mathrm{CH}_{3} \mathrm{C}_{6} \mathrm{H}_{4} \mathrm{SO}_{3} \mathrm{H}, \mathrm{SbF}_{3}$, or even $\mathrm{H}_{2} \mathrm{PtCl}_{6}$, the yield of acetophenone proved to be significantly lower than that obtained with the $\mathrm{PtCl}_{4}-\mathrm{CO}$ complex.

3.8 Partial resolution of a racemic alkyne via hydration by Pt-CO in the presence of a chiral ligand 
The ability to replace part of the carbonyl groups of the $\mathrm{PtCl}_{4}-\mathrm{CO}$ system by an optically active phosphine ligand lead us to investigate the possibility of kinetic resolution of a chiral alkyne. Thus, 1,3,5-triphenylpent-4-yn-1-one, $\mathrm{C}_{6} \mathrm{H}_{5} \mathrm{COCH}_{2} \mathrm{CH}\left(\mathrm{C}_{6} \mathrm{H}_{5}\right) \mathrm{C}=\mathrm{CC}_{6} \mathrm{H}_{5}$ (prepared best from diphenylacetone and [(3dimethylamino)propyl]bis(phenylethynyl)aluminum [9]), was hydrated in the presence of $\mathrm{PtCl}_{4}, \mathrm{CO}$, and $(R, R)$-DIOP under the conditions described in the Experimental Section until $20 \%$ of the starting material had disappeared. After chromatographic separation of the reaction mixture, $20 \%$ of the symmetrical 1,3,5-triphenyl-1,5-pentanedione [12] and starting alkyne which was resolved to the extent of 3\% were obtained. Although such low resolution is of no practical value, it proved the feasibility of asymmetric induction in alkynes during platinum-catalyzed hydration.

\subsection{Immobilization of the platinum-carbonyl catalyst}

The observation that the $\mathrm{PtCl}_{4}-\mathrm{CO}$ system tolerates the presence of tertiary phosphines allowed us to attach the platinum salt to a phosphinated polystyrene support. In a typical set of experiments, $0.25-0.65 \mathrm{mmol}$ of $\mathrm{PtCl}_{4}$ were bound to $1 \mathrm{~g}$ samples of $2 \%$ cross-linked polymer-bound diphenylphosphine on styrenedivinylbenzene co-polymer (0.62 mequiv. of $\mathrm{P} / \mathrm{g}$, beads, 20-60 mesh) in the conventional method [22], and the resulting immobilized platinum salt (washed with glyme and dried at $70^{\circ} \mathrm{C}$ in vacuo) was employed in the hydration of phenylacetylene under $200 \mathrm{psi} \mathrm{CO}$. A supported catalyst with P:Pt molar ratio of 1:1 lead to slow hydration to give $17 \%$ of acetophenone within $20 \mathrm{~min}$. Upon recycling of the catalyst the same yield was obtained in the second and third runs. Extension of the reaction time to $45 \mathrm{~min}$, lead to the 
formation of $38 \%$ of the ketone, but an approximately $20 \%$ reduction in yield occurred in each of the next runs. Reduction of the P:Pt ratio in the catalyst to 1:3, gave a relatively high yield (54\% in $20 \mathrm{~min}$ ) in the first run which however dropped sharply (to 7.5\%) in the second cycle.

The $\mathrm{PtCl}_{4}$ has been immobilized also by encapsulation in a silica sol-gel matrix [23]. The best catalyst was obtained when the sol-gel material was prepared under anhydrous conditions from $\mathrm{SiCl}_{4}$ (rather than from an alkoxy silane) in the presence of tert-BuOH [24]. Stirring of $\mathrm{PtCl}_{4}(0.1 \mathrm{mmol})$ in THF $(6 \mathrm{ml})$ in the presence of tert-BuOH $(3.2 \mathrm{ml})$ and $\mathrm{SiCl}_{4}(2 \mathrm{ml})$ for $6 \mathrm{~h}$ under $\mathrm{N}_{2}$ atmosphere at $25^{\circ} \mathrm{C}$ afforded heterogenized $\mathrm{PtCl}_{4}$ that hydrated phenylacetylene with aqueous glyme and CO (200 psi). In the first run $50 \%$ of acetophenone and $3 \%$ of styrene were obtained. In the second run, however, the yield of the ketone dropped to $20 \%$, and in the third run, the immobilized complex lost completely its power to catalyze hydration, although it continued to promote the transfer-hydrogenation of the alkyne to styrene for at least the next five runs.

\subsection{Catalytic transformation of the product}

As mentioned above, the main limitation of the hydration process is the condensation of the ketonic products that have $\mathrm{COCH}_{3}$ moieties to give oligomers and insoluble macromolecules. In fact, there exists the possibility that in some cases carboxaldehydes are formed in addition to ketones as primary products, but that they do not accumulate owing to their rapid depletion by condensation processes. While these condensations are usually slow and negligible during the first stages of the hydration, 
they may become significant when the process advances. Therefore, in some cases the accumulation of the ketones even decreases after a certain time. For example, when $\mathrm{C}_{6} \mathrm{H}_{5} \mathrm{CH}_{2} \mathrm{CH}_{2} \mathrm{C} \equiv \mathrm{CH}$ was hydrated under our standard conditions for $20 \mathrm{~min}$, the yield of $\mathrm{C}_{6} \mathrm{H}_{5}\left(\mathrm{CH}_{2}\right)_{2} \mathrm{COCH}_{3}$ was $16 \%$. Upon extension of the reaction time to $30 \mathrm{~min}$, only $13 \%$ of the desired ketone was left. The condensation process was found to be particularly significant when the $\mathrm{CO}$ gas was replaced by $\mathrm{N}_{2}$. In a typical experiment of phenylacetylene hydration by $\mathrm{PtCl}_{4}-\mathrm{N}_{2}$, the yield of acetophenone after 40 and $120 \mathrm{~min}$ was 33 and $16 \%$, respectively. We have shown that the hydration catalyst is also responsible for the polycondensation processes. When in a standard experiment of phenylacetylene hydration, that yielded normally $74 \%$ of acetophenone after $20 \mathrm{~min}$, the reagent was exchanged by alkyne-free acetophenone, $67 \%$ of the ketone underwent condensation. When a 1:1 mixture of phenylacetylene and acetophenone was placed in the reaction vessel the entire alkyne was consumed, but only $45 \%$ of monomeric acetophenone was left after $20 \mathrm{~min}$. A three-fold dilution with the medium (glyme) had no effect on the polymerization: the yield of the ketone was $74 \%$ as in the case of more concentrated reaction mixtures. The possibility that the polymerization takes place by a free radical process could be excluded on the basis of tests with free radical initiators and free radical scavengers. Neither addition of $5 \mathrm{mg}$ of hydroquinone nor of benzoyl peroxide had any effect on the accumulation of the macromolecules. Both additives decreased the rate of hydration to some extent, probably as the result of complexation with the catalyst. Under conditions that, in the absence of the additives, furnished $74 \%$ of acetophenone, we obtained 52 and $57 \%$ of the ketone, respectively, in their presence. 
On the other hand, the addition of bases (e.g., sodium acetate) strongly promoted the condensation reactions.

\subsection{Mechanistic considerations}

Our observation that aryl acetylenes with electron-donating substituents at the para-position are hydrated faster than those with electron-attracting groups may suggest that the addition of the water to the triple bond is an electrophilic, rather than a nucleophilic process. This is not in agreement with the previously proposed mechanism [1]. It would fit, however, a mechanism similar to the one suggested by Tele et al. for gold-promoted addition of alcohols to alkynes [25]. The first step in the catalytic cycle (step a in Scheme 1) is the addition of water to an alkyne complex of Pt(II). Step b is an intramolecular electrophilic attack of the oxonium moiety on the alkyne ligand, followed by transfer of an oxygen-bound hydrogen to the platinum bound carbon atom. The final step $\mathrm{d}$ is the release of ketone (in its enol form) from the $\mathrm{Pt}(\mathrm{IV})$ intermediate and addition of a new alkyne molecule which regenerates the initial $\mathrm{Pt}(\mathrm{II})$-alkyne complex. Support for this mechanism is found in the observation that non-hindered diarylacetylenes with electron-donating groups form as the main products ketones in which the carbonyl function is conjugated to the substituted phenyl ring, and vice versa. The alkynes with electron-attracting substituents give mainly ketones in which the carbonyl group winds up adjacent to the unsubstituted ring. The significant deuterium isotope effect indicates that the step which involves hydrogen transfer is rate-limiting. Thus, we assume that both steps $\mathrm{b}$ and $\mathrm{c}$ are slow and influence the rate. The proposed mechanism is also in agreement with XPS analysis of the residual catalyst which 
revealed that the platinum exists as a mixture of $\mathrm{Pt}(\mathrm{II})$ and $\mathrm{Pt}(\mathrm{IV})$ species, free $\operatorname{of} \operatorname{Pt}(0)$. We assume that during the reaction of $\mathrm{PtCl}_{4}$ with $\mathrm{CO}$ at least part of the $\mathrm{Pt}(\mathrm{IV})$ is reduced to $\mathrm{Pt}(\mathrm{II})$. In fact, $\mathrm{PtCl}_{4}$ and $\mathrm{PtCl}_{2}$ give under $\mathrm{CO}$ quite similar yields of ketones, but $\mathrm{PtCl}_{2}$ leads usually to more polymeric material than $\mathrm{PtCl}_{4}$.

\section{Acknowledgements}

We thank the United States-Israel Binational Science Foundation (BSF), for major support of this study through Grant No. 96-00093. K. P. C. V. is supported by the Director, Office of Energy Research, Office of Basic Energy Sciences, Chemical Sciences Division of the U.S. Department of Energy under contract DEAC03-76SF00098. The Center for New Directions in Organic Synthesis is supported by Bristol-Myers Squibb as Sponsoring Member. We also thank Professor Moris S. Eisen for performing XPS analyses and the Regis Technologies, Inc., Morton Grove, Illinois, for HPLC-separation of the enantiomers of 1,3,5-triphenylpent-4-yn-1-one, free of charge.

\section{References}

[1] W. Baidossi, M. Lahav, J. Blum, J. Org. Chem. 62 (1997) 669.

[2] I.D. Campbell, G. Eglington, Org. Synth. Coll. 5 (1973) 517.

[3] R. Wolovsky, F. Sondheimer, J. Am. Chem. Soc. 88 (1966) 421.

[4] Y. Badrieh, A. Kyyal, J. Blum, J. Mol. Catal. 75 (1972) 161.

[5] See (a) B.G. Van den Hoven, H. Alper, J. Org. Chem. 64 (1999) 3964; (b) R. Sauvêtre, J.F. Normant, Tetrahedron Lett. 23 (1982) 4325. 
[6] M. Andreas, Angew. Chem. Int. Ed. Engl. 12 (1973) 648.

[7] A. Carpita, R. Rossi, C.A. Verancini, Tetrahedron 41 (1985) 1919.

[8] K. Okuro, M. Furuune, M. Enna, M. Miura, M. Nomura, J. Org. Chem. 58 (1993) 4716.

[9] W. Baidossi, A. Rosenfeld, B.C. Wassermann, S. Schutte, H. Schumann, J. Blum, Synthesis (1996) 1127.

[10] S. Takahashi, Y. Kuroyama, K. Sonogashira, N. Hagihara, Synthesis (1980) 627.

[11] M. Chong, L. Shen, N.J. Taylor, J. Am. Chem. Soc. 122 (2000) 1822.

[12] S.S. Hirsch, W.J. Bailey, J. Org. Chem. 43 (1978) 4090.

[13] (a) J. Chatt, R.G. Guy, L.A. Duncanson, J. Chem. Soc. (1961) 827; (b) M.H. Chisholm, H.C. Clark, Inorg. Chem. 10 (1971) 2557; (c) W.C. Hisox, P.W. Jennings, Organometallics 9 (1990) 1997; (d) C.S. Browning, D.H. Farrer, Inorg. Chim. Acta 144 (1988) 105; (e) J.W. Hartman, W.C. Hiscox and P.W. Jennings, J. Org. Chem. 58 (1993) 7613); (f) W.C. Hiscox, J.W. Hartman, P.W. Jennings Inorg. Chim. Acta 222 (1994) 317.

[14] M. Sjöström, S. Wold, Chem. Scripta 9 (1976) 200.

[15] See e.g., H.H. Jaffe, Chem. Rev. 53 (1953) 191.

[16] T.K. Doughery, K.S.Y. Lau, F.L. Hedberg, J. Org. Chem. 48 (1983) 5273.

[17] Y. Badrieh, J. Blum, I. Amer, K.P.C. Vollhardt, J. Mol. Catal. 66 (1991) 295.

[18] See e.g., J.M. Smith, Chemical Engineering Kinetics, McGraw-Hill, New York, 1975, pp. 297-298.

[19] H. Bönnemann, G. Bram, W. Brijoux, R. Brinkmann, A.S. Tilling, K. Seevogel, K. Siepen, J. Organomet. Chem. 520 (1996) 143. 
[20] (a) J.C. Calabrese, L.L. Dahl, P. Chini, G. Longoni, S. Martinengo, J. Am. Chem. Soc. 96 (1974) 2614; (b) G. Longoni, P. Chini, J. Am. Chem. Soc. 98 (1976) 7225.

[21] N. Menashe, Y. Shvo, J. Org. Chem. 58 (1993) 7434.

[22] M. Capka, P. Svoboda, M. Kraus, J. Heftlejs, Chem. Ind. (London) (1972) 650.

[23] J. Blum, D. Avnir, H. Schumann, Chemtech. 29 (1999) 32.

[24] J. Blum, F. Gelman, R. Abu-Reziq, I. Miloslavski, H. Schumann, D. Avnir, Polyhedron 19 (2000) 509.

[25] H. Teles, S. Brode, M. Chabannas, Angew. Chem. Int. Ed. 37 (1998) 1415. 
Table 1. Hydration of representative alkynes by the $\mathrm{PtCl}_{4}-\mathrm{CO}$ catalyst in aqueous glyme $^{a}$

Entry Substrate

Reaction Hydration and main low-

time (h) boiling byproducts (yield, $\%)^{\mathrm{b}}$

\begin{tabular}{|c|c|c|c|}
\hline 1 & $\mathrm{CH}_{3}\left(\mathrm{CH}_{2}\right)_{3} \mathrm{C} \equiv \mathrm{CH}^{\mathrm{c}}$ & 0.33 & $\mathrm{CH}_{3}\left(\mathrm{CH}_{2}\right)_{3} \mathrm{COCH}_{3}(16)$ \\
\hline 2 & $\mathrm{C}_{6} \mathrm{H}_{5} \mathrm{C} \equiv \mathrm{CH}$ & 0.33 & $\mathrm{C}_{6} \mathrm{H}_{5} \mathrm{COCH}_{3}(74)$ \\
\hline 3 & $2-\left(\mathrm{C}_{4} \mathrm{H}_{3} \mathrm{~S}\right) \mathrm{C} \equiv \mathrm{CH}$ & 0.20 & 2-( $\left(\mathrm{C}_{4} \mathrm{H}_{3} \mathrm{~S}\right) \mathrm{COCH}_{3}(30)$ \\
\hline 4 & $\mathrm{C}_{6} \mathrm{H}_{5}\left(\mathrm{CH}_{2}\right)_{2} \mathrm{C} \equiv \mathrm{CH}^{\mathrm{d}}$ & 0.33 & $\mathrm{C}_{6} \mathrm{H}_{5}\left(\mathrm{CH}_{2}\right)_{2} \mathrm{COCH}_{3}(16)$ \\
\hline 5 & $\mathrm{C}_{6} \mathrm{H}_{5} \mathrm{C} \equiv \mathrm{CC}_{6} \mathrm{H}_{5} \mathrm{~d}, \mathrm{e}$ & 12 & $\begin{array}{l}\mathrm{C}_{6} \mathrm{H}_{5} \mathrm{COCH}_{2} \mathrm{C}_{6} \mathrm{H}_{5}(63) \text {, cis- } \mathrm{C}_{6} \mathrm{H}_{5} \mathrm{CH}=\mathrm{CHC}_{6} \mathrm{H}_{5} \\
(12) \text {, trans }-\mathrm{C}_{6} \mathrm{H}_{5} \mathrm{CH}=\mathrm{CHC}_{6} \mathrm{H}_{5}(24)\end{array}$ \\
\hline 6 & $2-\mathrm{C}_{10} \mathrm{H}_{7} \mathrm{C} \equiv \mathrm{CC}_{6} \mathrm{H}_{5}{ }^{\mathrm{d}}$ & 19 & $\begin{array}{l}2-\mathrm{C}_{10} \mathrm{H}_{7} \mathrm{COCH}_{2} \mathrm{C}_{6} \mathrm{H}_{5}(20) \\
2-\mathrm{C}_{10} \mathrm{H}_{7} \mathrm{CH}_{2} \mathrm{COC}_{6} \mathrm{H}_{5}(20)\end{array}$ \\
\hline 7 & $\mathrm{C}_{6} \mathrm{H}_{5} \mathrm{C} \equiv \mathrm{CC} \equiv \mathrm{CC}_{6} \mathrm{H}_{5}$ & 5 & $\begin{array}{l}\mathrm{C}_{6} \mathrm{H}_{5} \mathrm{COCH}_{2} \mathrm{C} \equiv \mathrm{CC}_{6} \mathrm{H}_{5}(67), \\
\text { cis- } \mathrm{C}_{6} \mathrm{H}_{5} \mathrm{CH}=\mathrm{CHC} \equiv \mathrm{CC}_{6} \mathrm{H}_{5}(9), \\
\text { trans }-\mathrm{C}_{6} \mathrm{H}_{5} \mathrm{CH}=\mathrm{CHC} \equiv \mathrm{CC}_{6} \mathrm{H}_{5}(20)\end{array}$ \\
\hline & $\equiv \mathrm{C}\left(\mathrm{CH}_{2}\right)_{2} \mathrm{C} \equiv \mathrm{C}\left(\mathrm{CH}_{2}\right)_{2} \mathrm{C} \equiv \mathrm{CH}$ & 0.33 & $\begin{array}{l}\mathrm{CH}_{3} \mathrm{CO}\left(\mathrm{CH}_{2}\right)_{2} \mathrm{CO}\left(\mathrm{CH}_{2}\right)_{3} \mathrm{C} \equiv \mathrm{CH}(9), \\
\mathrm{CH}_{3} \mathrm{CO}\left(\mathrm{CH}_{2}\right)_{3} \mathrm{CO}\left(\mathrm{CH}_{2}\right)_{2} \mathrm{C} \equiv \mathrm{CH}(37) \\
\mathrm{CH}_{3} \mathrm{CO}\left(\mathrm{CH}_{2}\right)_{2} \mathrm{C} \equiv \mathrm{C}_{(}\left(\mathrm{CH}_{2}\right)_{2} \mathrm{COCH}_{3}(10)\end{array}$ \\
\hline 9 & $\mathrm{C}_{6} \mathrm{H}_{5} \mathrm{C} \equiv \mathrm{CCO}\left(\mathrm{CH}_{2}\right)_{2} \mathrm{CH}_{3}$ & 2.25 & $\begin{array}{l}\mathrm{C}_{6} \mathrm{H}_{5} \mathrm{COCH}_{2} \mathrm{CO}\left(\mathrm{CH}_{2}\right)_{2} \mathrm{CH}_{3}(83),{ }_{1}^{\mathrm{f}} \\
\mathrm{C}_{6} \mathrm{H}_{5} \mathrm{CCl}=\mathrm{CHCO}\left(\mathrm{CH}_{2}\right)_{2} \mathrm{CH}_{3}(4), \\
\mathrm{C}_{6} \mathrm{H}_{5} \mathrm{COCH}=\mathrm{CCl}\left(\mathrm{CH}_{2}\right)_{2} \mathrm{CH}_{3}(2)\end{array}$ \\
\hline
\end{tabular}

$10 \mathrm{H}_{2} \mathrm{C}=\mathrm{C}\left(\mathrm{CH}_{3}\right) \mathrm{C} \equiv \mathrm{C}\left(\mathrm{CH}_{2}\right)_{2} \mathrm{CH}\left(\mathrm{CH}_{3}\right)_{2} \quad 1.25$

$\mathrm{H}_{2} \mathrm{C}=\mathrm{C}\left(\mathrm{CH}_{3}\right) \mathrm{CH}_{2} \mathrm{CO}\left(\mathrm{CH}_{2}\right)_{2} \mathrm{CH}\left(\mathrm{CH}_{3}\right)_{2}(68)$

$\mathrm{H}_{2} \mathrm{C}=\mathrm{C}\left(\mathrm{CH}_{3}\right) \mathrm{COCH}_{2}\left(\mathrm{CH}_{2}\right)_{2} \mathrm{CH}\left(\mathrm{CH}_{3}\right)_{2}(5)$

$\mathrm{H}_{2} \mathrm{C}=\mathrm{C}\left(\mathrm{CH}_{3}\right) \mathrm{CH}=\mathrm{CH}\left(\mathrm{CH}_{2}\right)_{2} \mathrm{CH}\left(\mathrm{CH}_{3}\right)_{2}(2)$

\footnotetext{
a Reaction conditions: $7.5 \mathrm{mmol}$ alkyne, $0.15 \mathrm{mmol} \mathrm{PtCl}_{4}, 200 \mathrm{psi} \mathrm{CO}, 2 \mathrm{ml} 92 \%$ aqueous glyme, $108^{\circ} \mathrm{C}$, stirring rate $350-400 \mathrm{rpm}$. ${ }^{\mathrm{b}}$ The yields given are the average of at least two experiments that did not differ by more than $\pm 3 \%$. Under these conditions the remaining percentages usually reflect the unreacted alkyne (within 1-3\%). c $92 \%$ Aq. diglyme was used as solvent. ${ }^{\mathrm{d}} 0.75 \mathrm{Mmol}^{\mathrm{P}} \mathrm{PtCl}_{4}$ was used. ${ }^{\mathrm{e}} \mathrm{At} 112^{\circ} \mathrm{C}^{\mathrm{f}}$ As a mixture of the keto and enol tautomers.
} 
Table 2. Effect of the concentration of the water on the hydration of phenylacetylene

\begin{tabular}{|c|c|c|c|}
\hline$\frac{\text { Amol }}{(\%)}$ & $\frac{\text { of } \mathrm{H}_{2}}{[\mathrm{M}]}$ & $\begin{array}{c}10^{4} \text { (Initial rate) } \\
\mathrm{mol} \mathrm{l}^{-1} \mathrm{~s}^{-1}\end{array}$ & $\begin{array}{l}\text { Yield of acetophenone } \\
\text { after } 12 \mathrm{~min}, \%\end{array}$ \\
\hline 4 & 2.22 & 4.69 & 9 \\
\hline 8 & 4.44 & 13.3 & 26 \\
\hline 12 & 6.52 & 14.1 & 27 \\
\hline 15 & 8.35 & 3.13 & 6 \\
\hline 17 & 9.45 & 1.56 & 3 \\
\hline 20 & 11.1 & 0.52 & 1 \\
\hline
\end{tabular}

a Reaction conditions: $7.5 \mathrm{mmol}$ phenylacetylene in $2 \mathrm{ml}$ of diglyme, $0.15 \mathrm{mmol}$ $\mathrm{PtCl}_{4}, 200$ psi CO, $108^{\circ} \mathrm{C}$, stirring rate $390 \mathrm{rpm}$. 
Table 3. Dependence of the initial rate of acetophenone formation on the concentration of phenylacetylene ${ }^{\text {a }}$

Initial concentration of phenylacetylene, $\mathrm{M}$
$10^{3}$ (Initial rate)

mol 1-1 $\mathrm{S}^{-1} \mathrm{~b}$
0.937

1.500

1.875

2.500

3.750

4.125

4.687
1.24

1.22

1.18

1.20

1.05

0.90

0.81

a Reaction conditions: $0.15 \mathrm{mmol} \mathrm{PtCl}_{4}, 200$ psi CO, $2 \mathrm{ml}$ diglyme, $108^{\circ} \mathrm{C}$, stirring rate 390 rpm. bach datum is the average of at least two results that do not differ by more than \pm $3 \%$. 
Table 4. Hydration of several diphenylacetylene derivatives under comparable conditions $^{a}$

Entry Substrate Yield of individual ketones (\%)

1

$4-\mathrm{CH}_{3} \mathrm{C}_{6} \mathrm{H}_{4} \mathrm{C} \equiv \mathrm{CC}_{6} \mathrm{H}_{5}$

4- $\mathrm{CH}_{3} \mathrm{C}_{6} \mathrm{H}_{4} \mathrm{COCH}_{2} \mathrm{C}_{6} \mathrm{H}_{5}$ (29)

$4-\mathrm{CH}_{3} \mathrm{C}_{6} \mathrm{H}_{4} \mathrm{CH}_{2} \mathrm{COC}_{6} \mathrm{H}_{5}$ (11)

2

$\mathrm{C}_{6} \mathrm{H}_{5} \mathrm{C} \equiv \mathrm{CC}_{6} \mathrm{H}_{5}$

$\mathrm{C}_{6} \mathrm{H}_{5} \mathrm{COCH}_{2} \mathrm{C}_{6} \mathrm{H}_{5}(18)$

3

$4-\mathrm{FC}_{6} \mathrm{H}_{4} \mathrm{C} \equiv \mathrm{CC}_{6} \mathrm{H}_{5}$

$4-\mathrm{FC}_{6} \mathrm{H}_{4} \mathrm{CH}_{2} \mathrm{COC}_{6} \mathrm{H}_{5}(24)$

$4-\mathrm{FC}_{6} \mathrm{H}_{4} \mathrm{COCH}_{2} \mathrm{C}_{6} \mathrm{H}_{5}$ (6)

4

$4-\mathrm{ClC}_{6} \mathrm{H}_{4} \mathrm{C} \equiv \mathrm{CC}_{6} \mathrm{H}_{5}$

$4-\mathrm{ClC}_{6} \mathrm{H}_{4} \mathrm{CH}_{2} \mathrm{COC}_{6} \mathrm{H}_{5}$ (11)

$4-\mathrm{ClC}_{6} \mathrm{H}_{4} \mathrm{COCH}_{2} \mathrm{C}_{6} \mathrm{H}_{5}$ (5)

5

$4-\mathrm{O}_{2} \mathrm{NC}_{6} \mathrm{H}_{4} \mathrm{C} \equiv \mathrm{CC}_{6} \mathrm{H}_{5}$

$4-\mathrm{O}_{2} \mathrm{NC}_{6} \mathrm{H}_{4} \mathrm{CH}_{2} \mathrm{COC}_{6} \mathrm{H}_{5}$ (6)

$4-\mathrm{O}_{2} \mathrm{NC}_{6} \mathrm{H}_{4} \mathrm{COCH}_{2} \mathrm{C}_{6} \mathrm{H}_{5}$ (3)

6

$2-\mathrm{CH}_{3} \mathrm{C}_{6} \mathrm{H}_{4} \mathrm{C} \equiv \mathrm{CC}_{6} \mathrm{H}_{5}$

2- $\mathrm{CH}_{3} \mathrm{CH}_{2} \mathrm{COC}_{6} \mathrm{H}_{5}$ (2.5)

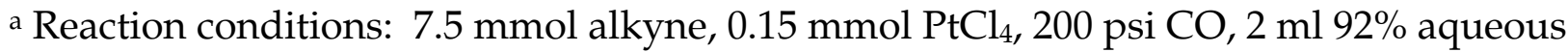
glyme, $108^{\circ} \mathrm{C}, 3 \mathrm{~h}$. 


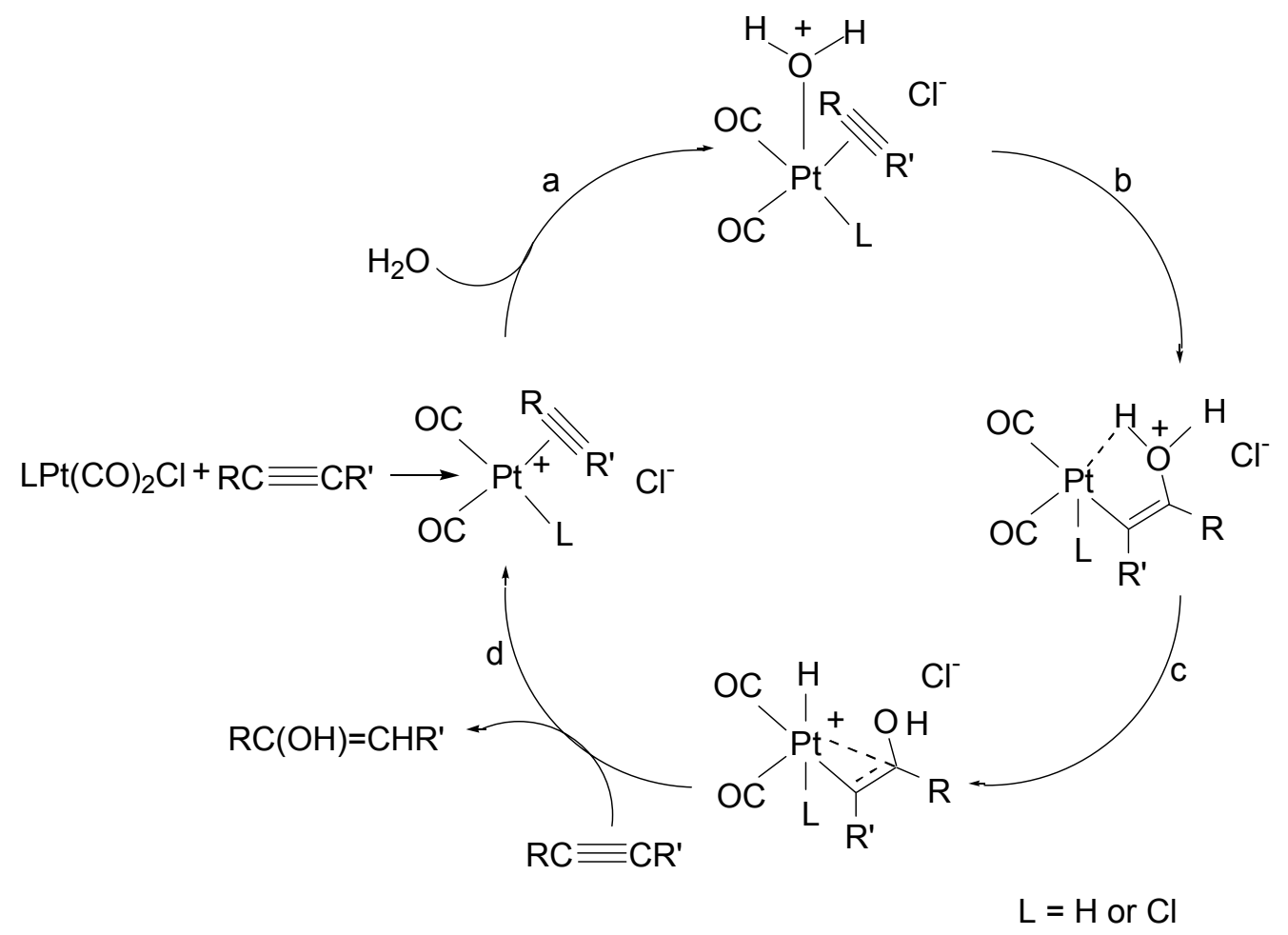

Scheme 1. Proposed mechanism for the hydration of alkynes by the $\mathrm{PtCl}_{4}-\mathrm{CO}$ catalyst 